\title{
Bilateral internal thoracic artery use-Are the results of one center generalizable to others?
}

\author{
Terry Shih, MD, MSc, ${ }^{a}$ and Richard Lee, MD, MBA ${ }^{\mathrm{b}}$ \\ From the ${ }^{\mathrm{a} D e p a r t m e n t}$ of Cardiac Surgery University of Michigan, Ann Arbor, Mich; and ${ }^{\mathrm{b}}$ Center for Compre- \\ hensive Cardiovascular Care, Saint Louis University, St Louis, Mo. \\ Disclosures: Authors have nothing to disclose with regard to commercial support. \\ Received for publication Jan 31, 2018; accepted for publication Feb 11, 2018; available ahead of print March 15, \\ 2018. \\ Address for reprints: Richard Lee, MD, MBA, Center for Comprehensive Cardiovascular Care, Saint Louis Uni- \\ versity, 3635 Vista Ave, DT 13F, St Louis, MO 63110 (E-mail: rlee@slu.edu). \\ J Thorac Cardiovasc Surg 2018;155:2344-5 \\ $0022-5223 / \$ 36.00$ \\ Copyright $(2) 2018$ by The American Association for Thoracic Surgery \\ https://doi.org/10.1016/j.jtcvs.2018.02.030
}

With the support of a growing body of evidence for bilateral internal thoracic artery (BITA) use, ${ }^{1,2}$ practice guidelines encourage cardiac surgeons to use BITAs for coronary artery bypass grafting (CABG). ${ }^{3,4}$ However, many surgeons remain resistant to routine BITA use, especially in high-risk populations. Nationwide, BITA use has remained flat at $<5 \%$. ${ }^{5,6}$ Furthermore, although retrospective reviews have reported improved survival, the only multicenter randomized controlled trial, currently ongoing, did not; moreover, BITA use increased sternal wound infections. ${ }^{7}$

In this issue, Saran and colleagues ${ }^{8}$ present a single-institution retrospective review of a large patient cohort comparing BITA versus left internal thoracic artery (LITA) alone use over 16 years. High-risk patients did not experience adverse effects on survival with BITA use. To minimize treatment selection bias, the authors used propensity score matching to account for baseline differences in the patient populations. Even after excluding more than 4000 patients in the LITA-alone group, the authors were able to examine more than 1000 in each intervention arm.

The study was clearly well-powered. However, we caution the reader to infer too much from this singleinstitution retrospective review. The institution averaged 400 CABGs per year over the 16-year study period, with $27 \%$ BITA use in the final year of the study period. It is uncertain whether lower-volume institutions with less expertise in BITA use would achieve similar results. In addition, BITA use was $14 \%$ at the beginning of the study period. This increase in use suggests a learning curve that was likely placed on the lower-risk population, who could better tolerate error. This may not be pragmatic in lower-volume centers. Moreover, surgeon-level analysis was not provided. It may be that a subset of technically superior surgeons performed a large bulk of the BITA CABGs, which may account for some of the difference.

One aim of the analysis of Saran and colleagues ${ }^{8}$ was to determine whether BITA use was associated with a survival

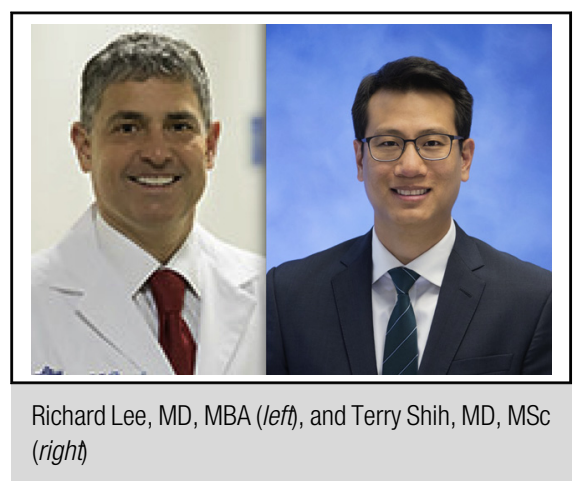

\section{Central Message}

Bilateral internal thoracic artery use has remained flat nationwide at $<5 \%$. One center's improved survival, even in high-risk populations, may not be generalizable to other centers.

See Article page 2331. advantage in high-risk populations. They examined this by performing an interaction analysis, which helps inform us on possible effect modifiers; however, it may be more informative to have performed subset analysis in specific high-risk patient groups. Furthermore, we are not presented whether sternal wound infection rates were increased in these high-risk patient groups. The study did demonstrate that overall sternal wound infection rates were greater in the BITA cohort than the LITA-alone cohort $(3.1 \%$ vs $1.4 \%, P=.01)$ and deep sternal wound infection rates were greater as well, although the event rate of this devastating complication is too low for this to be statistically significant $(1.2 \%$ vs $0.5 \%, P=.088)$. It is also important to consider that a small fraction of patients may have had an injured second internal thoracic artery (ITA) that could not be used as a conduit. For the purposes of this analysis, these patients would be considered as single-ITA patients. However, they would be exposed to the same risk as BITA patients for sternal wound issues.

Additional details relevant to surgical technique may help clarify the controversy with BITA use. The method of ITA harvest (skeletonized vs pedicled) was not analyzed. This could make a difference in wound infection rates and long-term patency rates. Quality of vessel targets were also not provided. Patients who underwent BITA use may have had better distal targets, which may account for the improved survival. Similarly, no data were presented 
regarding the long-term patency rates of bypasses in this study. Finally, although survival is an important outcome measure, further data about patient quality of life and other patient-centered outcomes are needed.

In conclusion, although Saran and colleagues ${ }^{8}$ have demonstrated strong evidence of a survival advantage at their center, is this evidence strong enough to overcome surgeons' hesitancy and move the needle on BITA use? Unfortunately, due to the study's limited generalizability to standard practice, the answer is likely "no" for now.

\section{References}

1. Yi G, Shine B, Rehman SM, Altman DG, Taggart DP. Effect of bilateral internal mammary artery grafts on long-term survival: a meta-analysis approach. Circulation. 2014;130:539-45.

2. Locker C, Schaff HV, Dearani JA, Joyce LD, Park SJ, Burkhart HM, et al. Multiple arterial grafts improve late survival of patients undergoing coronary artery bypass graft surgery: analysis of 8622 patients with multivessel disease. Circulation. 2012;126:1023-30.

3. Aldea GS, Bakaeen FG, Pal J, Fremes S, Head SJ, Sabik J, et al. The Society of Thoracic Surgeons Clinical Practice Guidelines on Arterial Conduits for Coronary Artery Bypass Grafting. Ann Thorac Surg. 2016;101:801-9.

4. Hills LD, Smith PK, Anderson JL, Bittl JA, Bridges CR, Byrne JG, et al. 2011 ACCF/AHA Guideline for Coronary Artery Bypass Graft Surgery: a report of the American College of Cardiology Foundation/American Heart Association Task Force on Practice Guidelines. Circulation. 2011;124:e652-735.

5. Falk V. Coronary bypass grafting with bilateral internal thoracic arteries. Heart. 2013;99:821.

6. Elbardissi AW, Aranki SF, Sheng S, O'Brien SM, Greenberg CC, Gammie JS Trends in isolated coronary artery bypass grafting: an analysis of the Society of Thoracic Surgeons adult cardiac surgery database. J Thorac Cardiovasc Surg. 2012;143:273-81.

7. Taggart DP, Altman DG, Gray AM, Lees B, Gerry S, Benedetto U, et al Randomized trial of bilateral versus single internal-thoracic-artery grafts. N Engl J Med. 2016;375:2540-9.

8. Saran N, Locker C, Said SM, Daly RC, Maltais S, Stulak JM, et al. Current trends in bilateral internal thoracic artery use for coronary revascularization: extending benefit to high-risk patients. J Thorac Cardiovasc Surg. 2018;155:2331-43. 